Ема Миљковић

Универзитет у Београду

Филолошки факултет

Катедра за оријенталистику

ema.miljkovic@fil.bg.ac.rs
271.222(497.11)-523.6(497.115)

https://doi.org/10.18485/ai_lik.2019.5.7.1

Оригинални научни рад

\title{
ПОЛОЖАЈ И СТАТУС ПЕЋКЕ ПАТРИЈАРШИЈЕ \\ ОД ПАДА ДЕСПОТОВИНЕ СРБИЈЕ ПОД ОСМАНСКУ ВЛАСТ ДО КРАЈА 16. ВЕКА
}

У овом раду аутор настоји да додатно осветли положај и статус Пећке патријаршије од пада Деспотовине Србије под османску власт 1459. године до краја 16. века. О овом питању у историографији још увек владају контроверзе, јер иако је сачуван ферман о обнови Пећке патријаршије 1557. године, документ о њеном укидању досад није пронађен. Стога се питање Пећке патријаршије у оквирима Османског царства у првом веку њихове владавине на овим просторима може разматрати само на основу посредних извора.

Кључне речи: Пећка патријаршија, Османско царство, Макарије Соколовић, 16. век.

Османским освајањем српских земаља, српска православна црква, иако подведена под систем османске власти, била је главни носилац очувања вере, народне традиције и осећања етничке припадности српском народу.

Након пада Смедерева, за време патријарха Арсенија II (1457-1463), османска држава признала је Пећку патријаршију и наметнула јој данак. Ранији историчари (Иларион Руварац, Константин Јиречек, Радослав Грујић) ${ }^{1}$ били су готово једнодушни у мишљењу да је након смрти Арсенија II, пећки трон запустео, те да је српска црква потпала под јурисдикцију Охридске архиепископије (Đurđev 1964).

1 Преглед ставова старије историографије дао је Бранислав Ђурђев. 
Опрезнији став налази сеу делима Љубомира Стојановића, који сматра да је и после пада Српске деспотовине било представника Српске православне цркве који нису били потчињени Охридској архиепископији, и Јована Радоњића, који тврди да српска црква није у целини изгубила своју самосталност после смрти Арсенија II (Стојановић 1923).

Бранислав Ђурђев је изнео свој став, који је прихваћен у новијој историографији, да су Османлије по заузимању Српске деспотовине признали српску цркву „онакву какву су је затекли” (Đurđev 1964). Извесно је да су јужне епархије, које су до тада биле под надлежношћу Пећке патријаршије 1455. године припојене Охридској архиепископији, док су под јурисдикцијом самосталне српске цркве у то време биле северна Србија (Смедеревски санџак), Босна и Херцеговине и Црна Гора. Иако се не сме олако одбацити могућност да ће евентуално проналажење неког оригиналног документа османске провинијенције бацити више светлости на питање деловања Пећке патријаршије у периоду до 1557. године, као посредан доказ њеног постојања и уважавања од стране османске власти њене активне верске улоге у српском народу могу се узети тужбе босанских фратара из манастира Фојнице, да им српски патријарх намеће дажбине, због чега су издати фермани којима се то забрањује (Đurđev 1964: 111-112).

Чињеница је да Пећки поменици после Арсенија II не спомињу ни једног српског архиепископа или патријарха пре Макарија, али то се може објаснити тиме што се сама Пећ налазила под јурисдикцијом Охридске архиепископије, а охридски архиепископи су се сматрали старешинама епархија у српским земљама. ${ }^{2}$ У записима из 1508. и 1509. године помиње се архиепископ Јован који влада црквама (Đurđev 1964: 106), тј. „седи на престолу св. Саве”. (Бошков 1992: 8, 13)

2 Сачуван је и ферман Бајазита II од 17. августа 1498. године, издат на притужбе становника Новог Брда и Сребрнице да су „патријарси и митрополити узели њиховим свештеницима новац, што до сада није било уобичајено". Ферманом се наређује да се то питање истражи и да се врати на пређашње стање. Међутим, у овом ферману нема

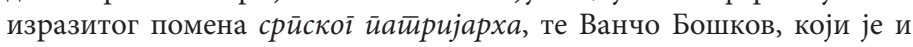
објавио ова документа, сматра да ту може бити реч о представницима Охридске архиепископије, дакле грчке цркве. 
Однос централне власти према свим конфесијама у Царству, па и према Пећкој патријаршији, мора се посматрати у ширем контексту политичких прилика и државних интереса, јер успостављање устројства цркава у Османском царству било је пре свега политичко, а не правно питање. Тако и настојања Грка да успоставе и учврсте своју власт над свим православним црквама у Османском царству најјасније се испољавају за време владавине великог везира грчког порекла Ибрахим-паше, који је на тој функцији био дуже од једне деценије, од 1523. до 1536. године. ${ }^{3}$ Српска црква је настојала да се супротстави успостављању апсолутне превласти Охридске архиепископије и преко ње Цариградске патријаршије (Благојевић и Медаковић 2000). Наиме, у другој половини XV и у првој половини XVI века, када је грчка доминација превасходно фискална, а у много мањој мери духовна, Српска православна црква показала је велику снагу и виталност (Историја српског народа III/2 1993).

У том контексту мора се посматрати и добро позната буна Павла Смедеревца, за коју у историографији постоји једногласна оцена да је она „значила озбиљан преокрет који сведочи о знатној самосталности српске цркве" (Историја српског народа III/2 1993: 22).

Та буна започела је крајем септембра 1527, а узрок јој је био званични акт којим се Пећка патријаршија ставља под јурисдикцију Охридске архиепископије. Наиме, охридски архиепископ Прохор (1523-1550) започео је борбу за припајање Пећке патријаршије Охридској архиепископији, када се на челу Цариградске патријаршије по други пут налазио Јеремија I (1523-1537) (Историја српског народа III/2 1993; Слијепчевић 2002; Пурковић 1976).

3 Уосталом, и сви српски великаши који су остали на територији под османском влашћу морали су бити лојални султану и без поговора извршавати његова наређења. Тако се понашала и султанија Мара, која је била побожна и одана православљу, али ништа није предузела, или није могла да предузме, да заштити интересе Српске православне цркве. Она се, наиме, у неколико махова ангажовала око избора цариградског патријарха, помагала је и светогорске манастире, али нема података да је пружала подршку српским епископима, митрополитима и патријарсима, већ је њено понашање било усклађено са званичном османском политиком. 
Више околности довело је до издавања таквог документа: то је био начин да патријарх Јеремија направи уступак архиепископу Прохору, а да избегне да он тражи враћање под јурисдикцију Охридске архиепископије оних области које су јој раније припадале, а које су се затим нашле у саставу Цариградске патријаршије. Постоји могућност и да је одлука о припајању издата услед нерегулисања материјалних обавеза Српске православне цркве према османској држави. Можда се баш Прохор обавезао да ће обезбедити плаћање свих дажбина, а сасвим је извесно, у складу са ондашњим обичајима, да је за издавање таквог акта морао да плати и мито (Đurđev 1964: 113-114).

Какви год да су били узроци томе чину, српско свештенство му се оштро супротставило. Њихов одговор био је избор Павла за архиепископа, који се у свим актима Охридске архиепископије титулише само као смедеревски митрополит. Како је један део српских црквених првака остао одан Охридској архиепископији, која је у међувремену успела да успостави своју превласт, Павле је почео да их смењује и да на њихово место поставља своје људе. У жељи да спречи побуну, архиепископ Прохор је између 01. септембра 1528. и 31. августа 1529. године сазвао Сабор, на коме су се појавили представници само оних епархија бивше Пећке патријаршије које су се од раније налазиле у саставу Охридске архиепископије. Павле је успео да се докопа Пећи и да се прогласи за патријарха, а чак му је пошло за руком да Прохор и још неки други епископи буду бачени у тамницу. За свој покрет Павле је, без сваке сумње, имао снажан друштвени ослонац. У то време православна црква у Смедеревском санџаку добро је материјално стајала, у документима се наводи да је Павле „имао подршку неких мирјана", али је сасвим извесно имао и подршку локалних османских власти. Наиме, у документима српске провинијенције има помена да су епископи које је постављао Павле

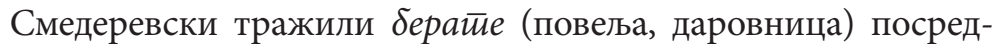
ством месних кадија, а не преко охридског кадије, као што је то било предвиђено султанским ферманом (декрет) из 1527. или 1528. године. Сасвим је извесно да без те подршке локалних власти Павлу никада не би успело да Прохор буде затворен. Ипак, период његовог заточеништва није дуго трајао, па 
је Прохор успео да добије ферман у корист Охридске архиепископије. На сабору у Охриду 13. марта 1532. године били су присутни и епископи из северне Србије, Босне и Херцеговине и Црне Горе. На сабору су учествовали епископи које је Прохор наименовао, а не они које је нешто раније поставио Павле, па се тако, међу учесницима, спомиње и смедеревски епископ Теодосије. Према документу са сабора, сачуваном у лошем препису, сазнаје се да је Павле присуствовао сабору, те да је признао своју кривицу. У одлуци сабора се наводи: „Стога и ми..., као што је речено једнодушно по божанственом закону сабора, упознавши сва бесправна и неправедна дела споменутог Павла, по овим божанственим правилима општим судом осудивши њега од свештенства излучисмо, с тим да буде извргнут и лишен свештенства свога, и с њим скупа такође од њега посвећени епископи: Неофит Лесновски, Теофан Зворнички, Пахомије Краковски, и ти нека су као и Павле туђи свештеницима..." (Костић 1922: 34).

Овим одлукама сабора у Охриду није угушен бунт српских епископа и свештенства, које је и даље у највећој мери било против припајања Охридској архиепископији. И после сабора, Павле је наставио да освећује храмове, рукополаже свештенике и ђаконе, те да се и даље представља као архиепископ. Иако је српска црква званично потпала под власт Охридске архиепископије, има индиција да су ту власт у потпуности прихватале само њене јужне епархије, док су остале, без обзира на све, и даље релативно самостално деловале. ${ }^{4}$ Коначно, после упорних настојања, Прохору је успело да од султана Сулејмана Законодавца добије ферман којим се наређује успостављање пређашњег стања у Охридској архиепископији и њено сједињавање са српском црквом. У Охриду је 20. јула 1541. године, у присуству антиохијског патријарха Михајла и јерусалимског патријарха Кирила поново одржан сабор, на

4 Примера ради, напоменимо да се 1531. године помиње херцеговачки митрополит Марко, а на саборском акту потписан је херцеговачки епископ Максим, што би значило да је Марко смењен. Међутим, остало је забележено да је 1534 . године херцеговачки митрополит Марко осветио антимис, на основу чега се закључује да епископ Максим није могао да се одржи на челу херцеговачке епископије. 
коме су проклети Павле и сви епископи које је он посветио. Сам Павле после искључења из цркве 1541. године одлази у изгнанство. Путовао је, тражећи помоћ, по Русији, Пољској и Влашкој, где је приман као српски архиепископ. Ипак, политичке околности су биле такве да Српска православна црква није могла да очува своју самосталност, али се њен духовни живот и даље одвијао на темељу српских средњовековних традиција (Костић 1922; Đurđev 1964; Историја српског народа III/2 1993).

До званичне обнове рада Пећке патријаршије долази 1557. године, након великог османског војног успеха: освајања Темишварског Баната и оснивања Темишварског беглербеглука (1552). Како су Срби одиграли значајну улогу у овој војни, предвођени тадашњим румелијским беїлербеіом, а у време обнове трећим везиром Порте, Мехмед-пашом Соколовићем, обнова Пећке патријаршије била је нека врста награде за учешће у том походу. Такође, султан Сулејман Законодавац, који је тада био на османском трону, сматрао је да ће званичном обновом Пећке Патријаршије и тиме успоставом институције Патријарха српског, једноставније контролисати српски народ, у чију апсолутну оданост није био уверен. Преко институције патријарха, који је био не само духовни, већ у суштини и световни вођа свога народа, османска администрација је држала српски народ под окриљем личности и институције коју су поштовали, а која је у првим деценијама након обнове била про-османски оријентисана. Османска власт је од Пећке патријаршије наплаћивала годишњи трибут, као и таксу за $\delta е р а \bar{u}$ за постављање патријарха, кога је морао да потврди султан. Такође, такса је плаћана и кад би дошло до промена на султанском трону, као што је, уосталом, био случај са свим султановим поданицима који су вршили неку службу на основу царског берата (Историја српског народа III/2 1993).

За првог патријарха поново успостављене Патријаршије постављен је Макарије Соколовић, рођак Мехмед-паше, а затим следи низ патријарха из ове породице, који су, иако одани православљу и немањићкој традицији, истовремено били и лојални поданици османског владара (Фотић 2000).

Обнова Пећке патријаршије представља значајан моменат не само за духовни, већ и политички живот Срба који су живели у оквирима Османског царства. Црква је представљала једину 
српску средњовековну институцију која је званично опстала и у османском систему власти. Она је око себе окупљала сав српски народ, чувала православну веру и немањићку традицију и представљала велику брану исламизацији. У оним крајевима где је хришћанска црква (било православна или католичка) била слабо организована, степен исламизације био је много већи. Иако су дажбине које су плаћале биле значајне и у појединим тренуцима је било веома тешко прикупити их, заузврат је Пећка патријаршија добила слободно исповедање вере, слободно управљање црквеним имањима, слободно убирање дажбина од народа, свештеника и калуђера.

Обновом Пећка патријаршија добија своје међе, своју унутрашњу организацију, као и право на самосталну црквену политику. Уз патријарха, успостављен је и сабор, највише црквено тело, на коме су се доносиле најзначајније одлуке за Цркву и њене вернике, и које је бирало патријархе. Извесно је да је само првог патријарха, Макарија Соколовића, поставио лично Сулејман Законодавац својим берайом, док су потоњи патријарски бирани на саборима. Епископе је постављао сам патријарх. Патријаршија се делила на митрополије, епархије, а оне даље на парохије. Средином 17. века, у време свог највећег територијалног опсега, Пећка патријаршија састојала се између 40 и 50 митрополија и епархија (Историја српског народа III/2 1993).

Да је Пећка патријаршија играла и значајну политичку улогу међу Србима у Османском царству показује промена не само црквене политике, до које долази за време патријарха Јована II Кантула, који је први патријарх који није водио про-османску политику. Он долази на патријаршијски престо 1592. године, у предвечерје избијања Дугог рата (1593-1606). Како патријарх и црква у том рату стају на страну Хабзбуршке монархије, то је код Срба потакло жељу за ослобођењем од османске власти и успостављањем независне државе. Као одраз тог стремљења, организован је устанак Срба у Банату (1594. године) који предводио владика вршачки Тиодор Тиодоровић. Након почетних успеха устаника, побуна је крававо угушена, а сам владика Тиодоровић жив одран (Историја српског народа III/2 1993). 
Озбиљан удар на обновљену Пећку патријаршију представља мера коју доноси султан Селим II (1566-1574), а која се назива „откупом цркава и манастира”. Ова мера је, извесно, примењивана на територији читаве Румелије (назив којим се уобичајено дефинишу европске територије Османског царства), седамдесетих година XVI века, мада има података да су се поједини манастири „откупљивали” и деценију касније (Фотић 1996; Слијепчевић 2002).

Наиме, османска администрација је, уз образложење да се статус цркава и манастира мора ускладити са исламским законом, шеријатом, наложила да све православне цркве и

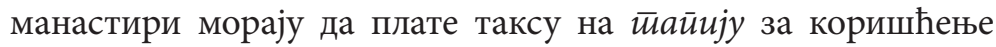
државне земље. Ипак, разлози су свакако првенствено економски, а делимично и политички. То је период када је већ почела да се осећа финансијска криза у Царству, те је ово био начин да се у Ризницу слију додатна средства. Такође, како административно, тако и територијално османска држава се учврстила на својим европским територијама, па су одређене повластице које су у ранијем периоду даване поданицима немуслиманима, у том тренутку, по процени османске централне власти могле бити укинуте.

Највећи и најзначајнији манастири који су имали економски снажна имања, попут Светогорских манастира, Милешеве, Дечана успели су да плате „таксу”, што сопственим средствима, што евентуалном продајом неких предмета из манстирске ризнице, или уз помоћ ктитора из православних земаља, као што су Русија, Влашка, Молдавија (Фотић 1996: 58-59).

Они са мањом економском снагом нису успели да плате таксу, те су често њихова имања откупљивали локални припадници османске владајуће класе, често они који су до тог периода задржали веру својих предака, и поред тога што су служили у османској војсци. Тако је, на пример, калуђерима манастира Старо Хопово, који нису могли сами да исплате прописану суму, у помоћ притекао извесни јузбаша Добросав из Ирига (Фотић 1996: 61).

Много већи проблем био је са црквама, јер оне нису имале имања, а ни могућности да потраже помоћ од ктитора из удаљених земаља, те су неретко бивале порушене. Управо у 
том периоду срушене су и две православне цркве у Београду, јер нису имале средстава да се откупе (Đurđev 1957).

У временима која долазе, Пећка патријаршија ће настојати да, упркос великим притисцима, одржи вернике и имовину. Поред сталне контроле османских власти да црквене власти не злоупотребе свој положај, све јачи су били и притисци папе за остваривањем уније. Такође, како се материјално стање у Османском царству погоршавало, пред Пећку патријаршију постављани су све већи намети. Поред прихода са манастирских имања, црквени поглавари су често путовали у „писанију”, код православних владара Русије, Влашке, Молдавије, молећи за помоћ и прикупљајући дарове. Управо од 17. века, све је присутнија помоћ, али и утицај Руске православне цркве на Пећку патријаршију (Миљковић 2005).

\section{Извори и литература}

Благојевић, Милош и Дејан Медаковић. Исӣорија срйске gржавно$c \bar{u} u$. Нови Сад: Српска академија наука и уметности, 2000.

Đurđev, B. „Prodaja crkava i manastira za vreme vlade Selima II”. Godišnjak istorijskog društva Bosne i Hercegovine IX (1957): 241-247.

Đurđev, B. Uloga crkve u starijoj istoriji srpskog naroda. Sarajevo: Svjetlost, 1964.

Бошков, В. „Турски документи о односу католиче и православне цркве у БиХ и Далмацији XV-XVII века". Сйоменик САНУ СXXXI, Оgељьне исторојских наука 7 (1992).

Исйорија срйской нароgа III/1. Београд: Српска књижевна задруга, 1993.

Исииорија срӣскої нароgа III/2. Београд: Српска књижевна задруга, 1993.

Костић, П. „Документи о буни смедеревског епископа Павла против потчињења Пећке патријаршије архиепископији Охридској”. Сйоменик LVI (1922): 3-57.

Миљковић, Е. „Крстарећи Османским царством”. А Фотић (ур.).

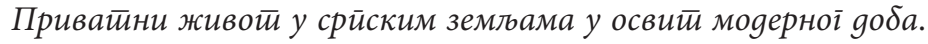
Београд: Clio, 2005. 173-196.

Пурковић, М. Срйски йайријарси среgюеї века. Диселдорф, 1976.

Радонић, J. Римска курија и јужнословенске земље оg XVI go XIX века. Београд: САНУ, 1950. 
Слијепчевић, Ђ. Исйорија Срйске Православне Цркве I, og йокршйаваюа Срба gо краја XVIII века. Београд: БИГЗ, 2002.

Стојановић, Љ. „Српска црква у међувремену од патријарха Арсенија II до Макарија око 1459-63. до 1557. г." Глас CVI (1923): 123.

Фотић, А. „Конфискација и продаја манастира (цркава) у доба Селима II (проблем црквених вакуфа)". Balcanica XXVII (1996): 45-77.

Фотић, А. Светиа Гора и Хиландар у Османском изарстиву XV-XVII век. Београд: Манастир Хиландар, 2000.

\title{
Ema Miljković
}

\author{
POSITION AND STATUS OF THE PATRIARCHATE \\ OF PEĆ SINCE THE FALL OF THE DESPOTATE \\ OF SERBIA UNDER THE OTTOMAN RULE \\ UNTIL THE END OF THE 16TH CENTURY
}

\section{Resume}

The aim of this paper is to clarify the position and status of the Patriarchate of Peć since the fall of the Despotate of Serbia under the Ottoman rule until the end of the $16^{\text {th }}$ century. This issue has yet not been resolved as a historiographical problem. The ferman (sultan's rescript) regarding the reestablishment of the Patriarchate has been well known in the historiography, but the one about the abolition, probably soon after the conquest of the Serbian capital of Smederevo, has not been found yet. Thus, this issue still needs a lot of elaboration and thinking under the sources which are not directly related to the abolition issue. However, this is one of the most critical issues of the history of the Serbian history under the Ottoman rule, since it is well known that the Serbian Orthodox Church was the only national institution that had operated under the Ottoman rule. Thus, the Church had the immense significance in the preservation or the national identity and traditional values for the Serbs under the centuries of the Ottoman rules.

Key Words: Patriarchate of Peć, the Ottoman Empire, Makarije Sokolovic, 16th century. 